UNIO - EU Law Jounal. Vol. 2, No. 2, June 2016, pp 123-139.

®2016 Centre of Studies in European Union Law

School of Law - University of Minho

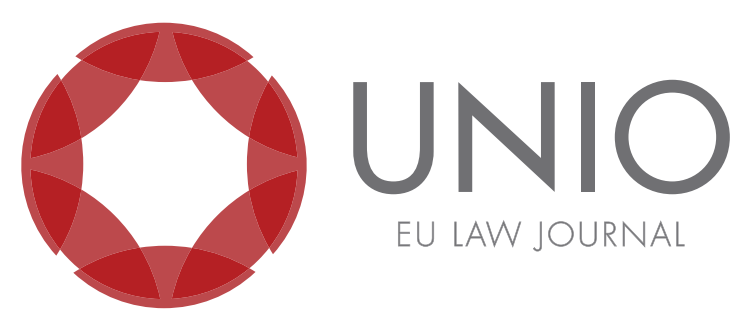

\title{
European asylum law. \\ Reality and challenges in the context of immigration
}

\author{
Ana Celeste Carvalho*
}

ABSTRACT: The protection of the rights of refugees and asylum seekers has become an important issue in legal discourse. This is primarily due to rising migration levels, precipitated by greater political and economic instability in overseas nation states such as Syria for example, which has been embroiled in a protracted civil war that has left the country in shambles and its people with no hope for the better future. As a result of large-scale migratory movements in the EU space today, it is a major challenge for Member States to comply with the Geneva Convention and $E U$ law concerning the protection of refugees and asylum seekers.

KEYWORDS: European asylum law - Convention of Geneva - refugees - asylum seekers.

\footnotetext{
* Appellate Judge. Coordinator of the Administrative and Tax Jurisdiction, and Judicial Trainer of Administrative Law, at the Centre for Judicial Studies, in Lisbon, Portugal.

This text is based on a speech delivered at the Seminar "The borders and the right without borders: migration, foreigners and globalization", organized by the Centre for Judicial Studies in Lisbon on 23 and 24 November 2015, in partnership with International Union of Portuguese Judges, the Community of Portuguese Language Countries (CPLP) and Instituto Padre Antonio Vieira.
} 
"Another aspect of integral human development that is worthy of attention is the phenomenon of migration. This is a striking phenomenon because of the sheer numbers of people involved, the social, economic, political, cultural and religious problems it raises, and the dramatic challenges it poses to nations and the international community."

[Benedict XVI, Encyclical Letter. Caritas in Veritate (29 June 2009), 62]

\begin{abstract}
"Migration movements, however, are on such a scale that only a systematic and active cooperation between States and international organizations can be capable of regulating and managing such movements effectively.

For migration affects everyone, not only because of the extent of the phenomenon, but also because of "the social, economic, political, cultural and religious problems it raises, and the dramatic challenges it poses to nations and the international community" (Caritas in Veritate, 62).

At the international level, frequent debates take place regarding the appropriateness, methods and required norms to deal with the phenomenon of migration. There are agencies and organizations on the international, national and local level which work strenuously to serve those seeking a better life through migration. (...)

Working together, however, requires reciprocity, joint-action, openness and trust, in the knowledge that "no country can singlehandedly face the difficulties associated with this phenomenon, which is now so widespread that it affects every continent in the twofold movement of immigration and emigration" (Message for the World Day of Migrants and Refugees 2014). (...) Vatican, September 3, 2014."
\end{abstract}

[Message of his Holiness Pope Francis for the 101st World Day of Migrants and Refugees (2015)]

\title{
1. General framework
}

The protection of the rights of refugees and asylum seekers has become an important issue that gained prominence, in light of increasing migration, precipitated by greater political and economic instability in many countries, some of which are dealing with armed conflicts and whose boundaries go well beyond Europe.

For many, Europe has become the continent where dreams can be fulfilled, where people are ensured decent employment and a proper residence, and children and young people are provided with an education and, therefore, the possibility of improved quality of life.

For this purpose, all rules, which will further the migrant's goal of establishing authorized residence in a country on the European continent or, if necessary, through refugee status or asylum, are used.

Recent forms of legal stay, ${ }^{1}$ other than refugee status or asylum, in international,

${ }^{1}$ In doctrine: Andreia Sofia Pinto De Oliveira, O direito de asilo na Constituição Portuguesa. Ambito de proteçãa de um direito fundamental, Coimbra Editora, 2009; Hélène Lambert, "Seeking Asylum. Comparative Law and Practice in Selected European Countries", in International Studies in Human Rights, Vol. 37, Martinus Nijhoff Publishers, 1995; François Crepeau, Droit d'asile. De l'hospitalite aux controles migratoire, Editions Bruylant, Editions de l'Université de Bruxelles, 1995; F. Garcia Da Rocha, "O direito de asilo no âmbito comunitário e no Acordo de Schengen", in Portugal, a Europa e as Migrações, Conselho Económico e Social, Lisboa, 1995, 213-225; Maria Teresa Tito De Morais, "Direito de procurar asilo noutros países", in Repensar a Cidadania, nos 50 anos da Declaração Universal dos Direitos do Homem, Notícias Editorial, 1998, 87-91; "A situação dos Refugiados no Mundo. Um Programa Humanitário", Alto Comissariado das Nações Unidas para os Refugiados, 1998; F. Jesus Carrera Hernandez, "El Derecho de Asilo de los Ciudadanos de la Union en el interior de la UE", in Revista de Instituciones Europeas, Vol. 22, n. ${ }^{\circ}$ 3, Madrid, 1995, 837-858; "Refugee Rights and Realities. Evolving International Concepts and Regimes", Frances Nicholson, Patrick Twomey (eds), Cambridge University Press, 1999; Teresa Cierco, A Instituição de Asilo na União Europeia, Almedina, Coimbra, 2010; Inês Filipa Pires Marinho, "O direito de asilo na União Europeia: problemas e soluções. Algumas reflexões em sede do quadro geral da Convenção de Genebra relativa ao estatuto do refugiado", in Estudos de Direito Europeu e Internacional dos Direitos Humanos, Ana Maria Guerra Martins (coord.), Almedina, 2005, 203-249; José Noronha Rodrigues, "A História do Direito de Asilo no Direito Internacional", in Temas de Integração, $1^{\circ}$ e $2^{\circ}$ Semestres de 2009, nos. 27 
European or even the national legal systems of the various Member States of the EU have achieved greater prominence in recent years as a result of the great migratory flow, which has been accompanied at times by changes in routes due to greater supervision and control over the entry of foreigners in some countries of Europe.

Despite the economic difficulties faced by some States, Europe retains its status as a continent of great opportunity for citizens from other countries and other continents, especially for those from Africa and countries of the Middle East.

Although these regimes are not recent, as throughout history there have been massive migratory movements, justifying their creation and regulatory framework, the growing instability in countries like Syria, Pakistan and Afghanistan, Iraq, Somalia, Nigeria, Mali, inter alia, has meant an increase of citizens of these nationalities entering Europe, sometimes through the protection provided by refugee status or asylum law, but other times, illegally because there is no legal in the international and European legal instruments, that allows for the entry and residence of such persons in Europe.

Therefore, it is of crucial importance to distinguish the various schemes and their assumptions, since asylum, refugee status or other forms of international protection do not have the same meaning or the same scope of protection.

Asylum is the oldest regime, dating back to the dawn of humanity, while the refuge and other forms of international protection, such as temporary protection and subsidiary protection are much more recent, having originated in the twentieth century.

Immigrants are those seeking better living conditions, voluntarily leaving their country for economic reasons. They are distinguished from refugees, those who are forced to move and leave their countries due to armed conflicts or for other reasons, and asylum seekers are those that apply for international protection because of the systematic violation of their most basic human rights, or because of danger or persecution. ${ }^{2}$

This is why asylum and refugee rights are grouped together; it is because there are causes that are common to both.

The grounds for granting asylum and refugee status are:

a) the persecution of individuals or groups resulting from armed conflict or as a result of the inertia or inaction of the State of origin in safeguarding social peace and security;

b) systematic violations of basic human rights, that could jeopardize or endanger the life or integrity of people and that are current and effective;

c) the abandonment of the country of origin or residence and relocation to another country;

d) the expectation of obtaining better protection and security in the third State;

e) the hope and belief of not being discriminated against and expelled or returned to their country of origin or residence, in accordance with the principles of non-

e 28, Almedina, 2009, 313-360 and "Políticas de asilo e de direito de asilo na União Europeia", in Scientia Ivridica, Jan./Mar. 2010, No. 321, 7-32; Maria Cláudia Da Silva Antunes De Souza/Lucas De Melo Prado, "The Statute of Refugees: Is it Applicable to Environmentally Displaced Persons?", in UNIO - EU Law Jounal, Vol. 1, No. 1, July 2015, 131-144 availabe at http://www.unio.cedu. direito.uminho.pt/Uploads/UNIO $\% 201 /$ The $\% 20$ Statute $\% 20$ of $\% 20$ Refugees $\% 20$ is $\% 20$ it $\% 20$ applicable $\% 20$ to $\% 20$ environmentally $\% 20$ displaced $\% 20$ persons formatado.pdf.

${ }^{2}$ The distinction may not be easy, particularly when the economic measures affecting the person are underpinned by reasons that are racial, political or religious in nature and are either directed at a particular group or compromise the survival of one group of the population, from which the victims of these discriminatory measures can become refugees. 
discrimination and non refoulement. ${ }^{3}$

At present, because they are closely related and have similar underlying motivations, asylum tends to encompass the concepts of both asylum and refuge.

Once refugee status is recognized, it is recognized internationally. This does not necessarily imply that asylum will be granted, but only that the rights provided for in the Geneva Convention ${ }^{4}$ and European normative instruments will be recognized.

This status is granted to those who fulfill the conditions laid down in Article 1 of the Geneva Convention:

i) to foreigners persecuted or seriously threatened by persecution as a result of their activities on behalf of democracy, social and national liberation, peace between peoples, freedom and the rights of the individual;

ii) to foreigners and stateless persons who are having well-founded fears of being persecuted for reasons related to race, religion, nationality, political opinion or membership of a particular social group - who are unable to or, owing to such fears, unwilling to return to the State of their nationality or habitual residence.

As a declaratory act granted by a Sovereign State to an alien or stateless person, asylum may have a wider scope than the protection afforded to refugees. This is because the protection stems from international and European law as well as from the state's domestic law, covering any person who, while not formally a refugee, is eligible for protection by the host state, whereas the protection of refugee stem from international and European law.

With regard to other forms of international protection, they arise in order to respond to other situations, embracing the large group of displaced persons or refugees that are not formally recognized as refugees or meet the requirements for the granting of asylum but nevertheless, are deserving of legal protection and more favorable treatment than other foreigners.

While these forms of international protection are not covered by the Geneva Convention, they are dealt with by European law; firstly by Directive 2001/55/EC of the Council of 20th July, with regard to the temporary protection and also by Directive 2004/83/EC of the Council of 29th April on subsidiary protection.

In the case of temporary protection, the issue concerned is the exceptional protection that seeks to respond to the massive influx of displaced persons from third countries who are unable to return to their origin country, for a specified period of time, by allowing people to enter and remain legally in the host country for a certain period of time. Subsidiary protection seeks to respond to situations involving people from third countries who, not having obtained European asylum, are in need of protection because they cannot return to their country of origin. This may be because of a serious situation caused by armed conflict or the systematic violation of fundamental rights; that is because of a humanitarian emergency. Those in this situation may be placed in a generic category of recipients, such as those from certain regions of the globe, designated as de facto refugees.

These are two forms of international protection for those who do not have refugee status under the Geneva Convention, but lack protection because they are

\footnotetext{
3 In this sense, cfr. Shova Devi, "Asilo, refúgio e outras formas de protecção internacional: relacionamento e diferenças conceptuais", in Newsletter, Global to Local News, 2015 - 09 - No. 2, p. 2-5.

${ }^{4}$ Relating to the Status of Refugees, adopted on 28 July 1951, which entered into force on 22 April 1954, in accordance with Article 43 and was amended by the New York Protocol of 31 January 1967 (hereinafter only Geneva Convention).
} 
unable to return to their country of origin due to the risk of suffering serious offences ${ }^{5}$ to their fundamental rights.

This means that European law, through subsidiary protection, extends the protection afforded by the Geneva Convention. It obliges Member States to protect the fundamental rights of foreigners who are particularly vulnerable, not just by abstaining from the practice of acts that jeopardize those rights, but also prohibiting their expulsion to territories where their fundamental rights are severely violated.

As soon as the requirements regarding international protection have been met, the Sovereign host State is bound to grant such protection and has no discretionary power to grant it or not to grant it.

Dispensed as European law and consequently accepted in the national law of the Member States, these regimes have become an important tool for protection, albeit with significant differences among them.

This reality is one of the challenges of building the Common European Asylum System (CEAS) and implementing the European policy on refugees, since at present, not all Member States have implemented the most recent Directives into their national law.

In the current context of increased difficulties and great challenges, sources regarding the international and European protection of refugees and asylum seekers are of crucial important in understanding European asylum law, which is why we will survey the main regulatory instruments.

Furthermore, in response to the need to question the suitability and effectiveness of the European policy on asylum and some of its regimes, we shall frame the right to asylum in the exclusion rules laid down in the Qualification Directive. This analysis will be done with reference (where applicable) being made to the jurisprudence of the Court of Justice the European Union (henceforth, CJEU).

\section{European asylum}

Under international and European law and the national law of each Member State, asylum is a right, affording protection to those who leave their country or place of residence for reasons related to security, freedom or survival, as a result of danger or persecution.

In order to analyze the sources of European asylum law, it is important to understand their main precursors, which are based on international instruments.

\subsection{Protection of asylum in international law}

The Universal Declaration of Human Rights (hereinafter, UDHR) ${ }^{6}$ made an

\footnotetext{
${ }^{5}$ What is meant by serious offense as defined in Article 15 (c) of Directive 2004/83/EC was subject to a decision of the Court of Justice of the European Union (CJEU), Grand Chamber, in Judgment Elgafaji, Case C-465/07, 17.02.2009, where in respect of a citizen from Iraq, it was decided: "the existence of a serious and individual threat to the life or person of an applicant for subsidiary protection is not subject to the condition that that applicant adduce evidence that he is specifically targeted by reason of factors particular to his personal circumstances; - the existence of such a threat can exceptionally be considered to be established where the degree of indiscriminate violence characterizing the armed conflict taking place - assessed by the competent national authorities before which an application for subsidiary protection is made, or by the courts of a Member State to which a decision refusing such an application is referred - reaches such a bigh level that substantial grounds are shown for believing that a civilian, returned to the relevant country or, as the case may be, to the relevant region, would, solely on account of his presence on the territory of that country or region, face a real risk. of being subject to that threat."

${ }^{6}$ Adopted by the United Nations General Assembly, by Resolution 217 A (III) of 10 December 1948.
} 
important contribution to international protection upon enshrining the "Right of asylum" in Article 14, in accordance with which; "Any person subject to persecution bas the right to seek and to enjoy in other countries asylum."

It was, however, the Geneva Convention on the Status of Refugees that took an enormous step forward in the international protection of asylum seekers and refugees.

It was through the concept of refugee ${ }^{8}$ and the regime conferring refugee status that the establishment of the principle of non refoulement prohibiting the return or expulsion of refugees to the country where they are victims of persecution, but also the situations that determine the cessation ${ }^{9}$ of the protection provided by the Convention and those that determine exclusion ${ }^{10}$ from that status, that the construction of asylum evolved.

The principle of non refoulement guarantees that the refugee cannot be expelled "to the frontiers of territories where his life or freedom would be threatened on account of his race, religion, nationality, social group or political opinion," "11 although it does not prevent a refugee's return by the State if that person poses a danger to the security of the country he or she is in or if, having been convicted of a serious offence, the person constitutes a threat to the population of that country. ${ }^{12}$

Alongside the concept of refugee and the establishment of the principle of non refoulement, the Geneva Convention bestows a real status on refugees, by defining the rights of refugees in reference to the rights granted to the nationals and foreigners of each state - such as the right to property, religious freedom, the exercise of the profession, housing, education, access to the courts, social security, travel documents, and others. ${ }^{13}$

Furthermore, it ensures that those who enter or stay illegally in a State - having come directly from a territory where their life or health was endangered or threatened - cannot be sanctioned criminally, specifically in cases of fake entry and/or residence documents or as a consequence of the manner of entry into the State, provided they submit to the authorities without delay and state the reasons for their illegal entry or presence. ${ }^{14}$

Though having refugee status ensures international protection, it is assessed

\footnotetext{
${ }^{7}$ By Resolution 319 A (IV) of 3 December 1949, the United Nations General Assembly created the United Nations High Commissioner for Refugees (UNHCR), which was established in January 1st., 1951, playing, since then, an important role in protecting the rights of refugees and the provision of support in the territory where they are.

${ }^{8}$ Provided for in Article 1-A (2), under which, "...as a result of events occurring before 1 January 1951, and for fear of being persecuted for reasons of race, religion, nationality, social group or political opinion, is outside the country of his nationality and is unable or, owing to such fear, is unwilling to avail the protection of that country...." The Additional Protocol to the Geneva Convention eliminated the timeframe provided for in the refugee notion, by providing that all refugees covered by the Convention definition should enjoy such status.

${ }^{9}$ Provided for in Article 1-C.

${ }^{10}$ Set out in Article 1, D, E and F.

${ }^{11}$ Set out in paragraph 1 of Article 33 of the Geneva Convention and reaffirmed in other legal instruments such as the United Nations Declaration on Territorial Asylum, adopted by the General Assembly United Nations, of 14 December 1967 [Resolution n. 2312 (XXII)], in Article 3 (1), and the Convention on the Status of Stateless Persons in Article 31(1).

${ }^{12}$ Under Article 33 (2) of the Geneva Convention.

${ }^{13}$ Cf. Articles 12 et seq. the Geneva Convention. Similar terms in the discipline the Convention on the Status of Stateless Persons, adopted in New York on September 28, 1954 and entered into force on 6 June 1960, according to Article 39. There is a parallelism regarding the rights granted between two Conventions.

${ }^{14}$ Vide Article 31.
} 
according to a procedure under the national law of each State. This does not mean that asylum must necessarily be granted, only that the set of rights under the Geneva Convention 1951 and other applicable instruments of legal protection are recognized.

Such is provided by Article 1 of the United Nations Declaration on Territorial Asylum (henceforth, UNDTA) ${ }^{15}$ according to which, asylum is granted by a State in the exercise of its sovereignty, to persons who are justified in invoking Article 14 UDHR. It is up to the State that grants the asylum to determine the underlying causes.

Without prejudice to the Sovereignty of States, it is assumed in Article 2 (1) of the Declaration that protection of the right to asylum is in the interest of the international community and is not, therefore, only a matter for the internal affairs of a country.

In addition, the Declaration has shown itself to be prescient by stating that; "where a state finds difficulty in granting or continuing to grant asylum, states individually or jointly or through the UN shall consider, in the spirit of international solidarity, appropriate measures to lighten the burden on that state." "16

The UNDTA establishes that; "temporary asylum"17 or another form of protection can be granted, acknowledging that other protection schemes can be provided, as indeed, was the case with those later established under the European legal order.

\subsection{Protection of the right to asylum in European law}

In addition to the international legal instruments, the European institutions have taken on a prominent role in the implementation and development of refugee protection and asylum.

Not only has the Council of Europe (Henceforth, CoE), since its inception, taken very significant steps in that direction, but also the European Court of Human Rights (hereinafter, ECtHR) and all the organs of the EU, have been in the forefront of these advances.

The European Convention on Human Rights (henceforth, ECHR), ${ }^{18}$ adopted by the CoE in 1950 and the Additional Protocols that followed, especially Protocol 4, dated from 1963, which in Article 4 provides for the prohibition of the collective expulsion of aliens and Protocol 7 of 1984 which set out the procedural safeguards relating to the expulsion of foreigners. These are the benchmarks in European asylum law.

Although the ECHR does not explicitly enshrine the right of asylum, it establishes a number of other rights, that States are obliged to respect and cannot be eschewed by the expulsion order.

In this respect, the human rights provided for in the Convention, such as the right to life, ${ }^{19}$ the prohibition of torture or subjection to inhuman or degrading

\footnotetext{
${ }^{15}$ Adopted by the United Nations General Assembly on 14 December 1967 [Resolution No. 2312 (XXII)].

${ }^{16}$ According to Article 2 (2). Analyzing the prospect of economic solidarity between the member States within the framework of the Common European Asylum System (CEAS), cf. Roland Bieber/ Francesco Maiani, “Sans solidarité point d'Union européenne. Regards croisés sur les crises de lUnion économique et monétaire et du Système européen commun d'asile", in Revue trimestrielle de droit européen, No. 2, Avril / Juin, Dalloz, 2012, 295-327.

${ }^{17}$ Cf. Article 3(3).

${ }^{18}$ Convention for the Protection of Human Rights and Fundamental Freedoms.

${ }^{19}$ Cf. Article 2.
} 
treatment, ${ }^{20}$ the right to liberty and security ${ }^{21}$ and the right to respect for family life, ${ }^{22}$ are called upon and take on greater significance in the protection of refugees' rights. As regards refugees, the CoE has adopted several instruments, among them:
a) the European Agreement on the Abolition of Visas for Refugees (1959); $;^{23}$
b) Resolution 14 on Granting Asylum to People threatened Chase (1967);
c) the Declaration Relative to Territorial Asylum (1977); ${ }^{24}$
d) the European Agreement on Transfer of Responsibility for Refugees (1980);
e) the Recommendation on Harmonization of National Procedures Relating to Asylum (1981); ${ }^{25}$
f) the Recommendation ${ }^{26}$ on the Protection of People who Meet the Criteria of the Geneva Convention and who are not Formally Recognized as Refugees (1984);
g) Recommendation No. 787 on Harmonization in eligibility matters relating to the Status of Refugees (1986); ${ }^{27}$
h) Recommendation No. 1088, on the right of territorial asylum (1988);
i) Dublin Convention (1990) on the determination of the State responsible for examining an asylum application lodged in one Member State, ${ }^{28}$
j) Recommendation No. 1237 on the requests for asylum which have been dismissed (1994). ${ }^{29}$

Under European law, the Dublin Convention has become quite important. It

\footnotetext{
${ }^{20}$ According to Article 3.

${ }^{21}$ Article 5.

${ }^{22}$ Cf. Article 8.

${ }^{23}$ Determines that refugees with legal residence in the territory of a Contracting Party are exempt from the formality of visas to enter the territory of the other contracting parties, provided that that they hold travel documents issued by the authorities of their usual residence and the duration of their stay does not exceed three months, regulating the terms under which the need for visas is abolished, and the movement of refugees takes place.

${ }^{24}$ In point 2, the Council of Europe reaffirmed its commitment to retain the right to asylum to any person who rightly fears being persecuted for reasons regarding race, religion, nationality, social group or political opinion and also fulfills the other conditions to be eligible for the Status of Refugees afforded by the Convention. However, it also extended the right of asylum "to anyone else who considers [the member states of the Council of Europe] wortby of receiving asylum for humanitarian reasons."

${ }^{25}$ Regulates the transfer of responsibility that has been verified at the end of the of two years of effective and uninterrupted stay of a refugee who is holder of a travel document issued by the first State, in the second State. Cf. "Rapport explicatif relatif à l`Accord européen sur le transfert de la responsabilité à l’égard des réfugiés”, Conseil de L'Europe, Strasbourg, 1980.

${ }^{26}$ Though it is concerned with a non-binding instrument, it contributes as a guide in building the common asylum and refugee policy within the European Union.

${ }^{27}$ It said that although the refugee status is based on the Geneva Convention, eligibility is determined according to very different procedures in the Member States that do not follow a single system, resulting in the adoption of very different criteria and recognition rates in the various states. It recommends the harmonization of eligibility.

${ }^{28}$ Adopted on 15 June 1990. It establishes criteria for determining which Member State is responsible for examining an asylum application when the person concerned has lodged it with the one or more Member States. In doctrine, cf. Concepcion Escobar Hernandez, "El convenio de aplicacion del acuerdo de Schengen y el convenio de Dublin: una proximacion al asilo desde la perspectiva comunitária", in Revista de Instituciones Europeas, Vol. 20, No. 1, Madrid, 1993, 53-100.

${ }^{29}$ Whose decision is up to the host country, in light of the principle of national sovereignty.
} 
was approved in the context of migration in Europe - having been motivated by the war in the former Yugoslavia - where the granting of refugee status and asylum depended on each Member State and where there was a lack of common and uniform rules among the various States, especially those that could prevent a citizen from a country outside the EU from filing a new application in another Member State, after a previous refusal. The Convention was meant to prevent asylum seekers from being sent from one State to another, with none considering themselves competent to examine the application for asylum, as well as to prevent applicants from submitting successive applications for asylum in several States, thus seeking to harmonize the common European asylum policy.

In June 1995, the EU Council adopted a Resolution on minimum guarantees for asylum procedures, which sought to safeguard the examination of asylum applications within the meaning of Article 3 of the Dublin Convention. It was meant to ensure fair and effective asylum procedures.

The Dublin Convention brought about changes at the level of the Treaties, because since then, there have been references to the protection of the right of asylum and refugees, and not just the free movement of persons.

The TEU, adopted in Maastricht, ${ }^{30}$ laid down common rules on the free movement of people and rules governing the movement of persons across external borders and the controls thereon, set immigration policy and for the first time, at the level the Treaties, referred to asylum policy. ${ }^{31}$ The Treaty of Amsterdam ${ }^{32}$ expanded and implemented this policy by establishing common rules for matters regarding reception and the control of external borders, asylum and those relating to temporary protection $^{33}$ and the Treaty of Nice did not change this reality. ${ }^{34}$

As a result of the conclusions of several European Councils - including one held in Tampere, Finland, on 15 and 16 October 1999, where the creation of an area of freedom, security and justice Union European was discussed - there have been several developments.

Regulation (EC) No. 2725/2000 of 11 December $2000^{35}$ established the Eurodac $^{36}$ system for the comparison of fingerprints for the effective application of the Dublin Convention, in order to identify asylum seekers and nationals of third countries entering the EU in an irregular manner, by comparing fingerprints, and checking to see if any applications were previously submitted in other Member States.

Hence, there was development in the common system of free movement of people, but at the same time in the control of borders, asylum and migration, within the area of freedom, security and justice.

Following this guideline, the Dublin Regulation ${ }^{37}$ was approved. It established

\footnotetext{
${ }^{30}$ Adopted on 11 December 1991 and entered into force on 1 November 1993.

${ }^{31}$ Cf. Article K1 in Title VI, "Provisions on cooperation in the field of justice and home affairs."

${ }^{32}$ Approved on 2 October 1997 and entered into force on 1 May 1999.

${ }^{33}$ Cf. Articles 73-I to 73-Q, in Title III-A, "Visas, asylum, immigration and other policies related to free movement of persons."

34 The Treaty of Nice (2001/C 80/1) introduced another systematization, going through the same provisions to match the Title IV, with the same title under Articles 61 to 69.

${ }^{35}$ In OJEU L 316, 15.12.2000.

${ }^{36}$ Designation of European Dactyloscopy.

${ }^{37}$ Regulation (EC) No. 343/2003 of the Council of 18 February 2003, known as Dublin II, applied to all Member States, including the UK and Ireland since 2006 and Denmark also, as well as Iceland, Norway, Switzerland and Liechtenstein, in OJEU L 50, 25.2.2003, p. 1-10. In light of the Dublin Regulation, a Member State is responsible for examining the asylum application where: (i) has issued
} 
the criteria mechanisms for determining the Member State responsible for examining the asylum application lodged in one of the Member States by a third-country national, thereby replacing the previous Convention.

The TFEU, in its consolidated version, ${ }^{38}$ defined a shared cooperation and competence, called freedom, security and justice in civil, criminal and police, border, visa, asylum and immigration matters, which lead to significant development in European asylum policy.

For the first time, in addition to the common asylum policy, the Treaties refer to subsidiary protection and temporary protection, designed to provide an appropriate status for any national of a third country in need of international protection, under the guarantee of the principle of non refoulement, as set out common procedures for granting and withdrawing asylum status and subsidiary protection. ${ }^{39}$

The philosophy that has permeated the construction of the common European asylum system has been to create a uniform system, the establishment of increasingly effective standards for the recognition and content of international protection.

On the other hand, the EU Charter of Fundamental Rights (Henceforth, CFREU) ${ }^{40}$ to which the Member States have committed themselves upon signing the Treaty of Lisbon, also establishes, in Article 18, the "Right to asylum"; “...shall be guaranteed with due respect for the rules of the Geneva Convention of 28 July 1951 and the Protocol of 31 January 1967 relating to the status of refugees and in accordance with the Treaty establishing the European Community."

In addition to prohibiting collective expulsions, Article 19 (1) of the Charter on the "Protection in the event of removal, expulsion or extradition," provides that; "No one may be removed, expelled or extradited to a State where there is a serious risk that he or she would be subjected to the death penalty, torture or other inbuman or degrading treatment or punishment."

an asylum seeker with a valid residence permit; (ii) issued an asylum seeker with a valid visa, unless it is issued on behalf of or with the written authorization of another Member State; (iii) for the Member State in which the applicant entered illegally by land, air or sea through a third country, and (iv) before it was submitted the request if the Member State can be designated responsible with on any of the above criteria.

${ }^{38}$ Cf. Treaty of Lisbon on 13 December 2007, entered into force on December 1, 2009, in Chapter 2, "Policies on border checks, asylum and immigration" under Articles 77 to 80, develops a common asylum policy.

${ }^{39}$ For its relevance, cf. Article 78 of the Treaty, according to which: "1.The Union shall develop a common policy on asylum, subsidiary protection and temporary protection with a view to offering appropriate status to any third-country national requiring international protection and ensuring compliance with the principle of nonrefoulement. This policy must be in accordance with the Geneva Convention of 28 July 1951 and the Protocol of 31 January 1967 relating to the status of refugees, and other relevant treaties.

2. For the purposes of paragraph 1, the European Parliament and the Council, acting in accordance with the ordinary legislative procedure, shall adopt measures for a common European asylum system comprising: (a) a uniform status of asylum for nationals of third countries, valid throughout the Union; (b) a uniform status of subsidiary protection for nationals of third countries who, without obtaining European asylum, are in need of international protection; (c) a common system of temporary protection for displaced persons in the event of a massive inflow; (d) common procedures for the granting and withdrawing of uniform asylum or subsidiary protection status;(e) criteria and mechanisms for determining which Member State is responsible for considering an application for asylum or subsidiary protection; (f) standards concerning the conditions for the reception of applicants for asylum or subsidiary protection; (g) partnership and cooperation with third countries for the purpose of managing inflows of people applying for asylum or subsidiary or temporary protection.

3. In the event of one or more Member States being confronted with an emergency situation characterized by a sudden inflow of nationals of third countries, the Council, on a proposal from the Commission, may adopt provisional measures for the benefit of the Member State(s) concerned. It shall act after consulting the European Parliament."

${ }^{40}$ Cf. OJEU 2000/C 364/01. 
(paragraph 2), establishing negative obligations of non facere, on Member States, protecting asylum seekers against removal, expulsion and extradition.

Therefore, as regards removal and expulsion, Member States must comply with binding international treaties such as the Geneva Convention, the ECHR and the Convention against Torture and Other Cruel, Inhuman or Degrading Punishments. ${ }^{41}$

By referring to the Treaty establishing the European Community, the right to asylum enshrined in Article 18 of CFREU subsumes the terms of the TEU and the TFEU linking all Member States. ${ }^{42}$

This means that all the European institutions, including the ECtHR and the CJEU along with the Member States, must obey the principles and rights enshrined in the CFREU in the implementation of EU law, among which Articles 18 and 19.

In this regard, the $\mathrm{CJEU},{ }^{43}$ in a case that concerned the defense of fundamental rights in relation to the prohibition of inhuman or degrading treatment, considered whether the decision of a Member State to examine whether or not an asylum application for which it is not responsible, triggers the application of EU law for the purposes of Article 6 TEU and/or Article 51 of CJEU.

European Directives followed; creating and developing protection systems:

i) Directive 2001/55/ EC of the Council of 20 June $2001,{ }^{44}$ established the minimum standards for temporary protection in the event of a mass influx of displaced persons and measures promoting a balance of assumed effort by Member States in receiving such persons and bearing the consequences thereof;

ii) Directive 2003/9/EC of the Council of 27 th January $2003^{45}$ established minimum standards for the reception of asylum seekers in Member States; iii) Directive 2004/83/EC of 29th April $2004^{46}$ on minimum standards for the qualification and status of third country nationals or stateless persons as beneficiaries of refugee status or persons who otherwise need international protection and concerning their status, and the content of the protection conferred; and

iv) Directive 2005/85/EC of the Council of 1 st December $2005,{ }^{47}$

\footnotetext{
${ }^{41}$ Vide Resolution No. 39/46 of the United Nations General Assembly on December 10, 1984, entered into force on June 26, 1987, in accordance with Article 27 (1).

${ }^{42}$ Pursuant to European case law, "respect for fundamental rights is 1) a condition of the legality of Community acts; 2) a binding parameter of the member states subject to legal control and political control; 3) a finalistic criteria framework of the cooperation actions and policies of the European Union", Maria Luisa Duarte, União Europeia e Direitos Fundamentais. No espaço da Internormatividade, AAFDL, Lisboa, 2006, 174, apud Plácido Conde Fernandes, "A detenção de estrangeiros e requerentes de asilo: um Direito sem fronteiras no mapa do Humanismo europeu", in Revista do Ministério Público, 125, Jan./Mar., 2011, 92.

${ }^{43}$ Cf. C-411/10 of 21.12.2011 (Grand Chamber).

${ }^{44}$ In OJEU L 212, p. 12-23.

${ }^{45}$ In OJEU L 31, p. 18-25. It provides a set of rights to the reception of asylum seekers.

${ }^{46}$ In OJEU L 304, p. 12-23. As amended by Directive 2011/95/EU of the European Parliament and of the Council of 13 December 2011 laying down rules on the qualification of third country nationals or stateless persons as beneficiaries of international protection, a uniform status for refugees or for persons eligible for subsidiary protection and the content of the protection granted. ${ }^{47}$ In OJEU L 326, p. 13-34. As amended by Directive 2013/32/EU of the European Parliament and of the Council of 26 June, on common procedures for granting and withdrawing international status, whose transposition, due by June 20, 2015. It is not yet a reality in all of the European Union, since it has not been implemented in some Member States.
} 
adopted minimum standards for granting and withdrawing refugee status in Member States.

The set of legislative measures that correspond to the Dublin Regulation and the Eurodac Regulation and the four preceding Directives, correspond to the first phase of the Common European Asylum System (CEAS). ${ }^{48}$

Legal protection in the European system would not be complete if other instruments were not approved:

a) Directive 2000/43 / EC of 29th June 2000 implementing the principle of equal treatment between persons irrespective of racial or ethnic origin; b) Directive 2000/78 / EC of 27th November 2000 establishing a general framework for equal treatment in employment and occupation;

c) Regulation (EC) No. 1030/2002 of 13th June 2002 establishing a model for residence permits for third-country nationals;

d) Directive 2003/86/EC of 22nd September 2003 concerning the right of family reunification;

e) Regulation (EC) No. 1560/2003 of 2nd September 2003 Commission on procedures for implementing Council Regulation (EC) No. 343/2003 establishing the criteria and mechanisms for determining the Member State responsible for examining an asylum application lodged in one of the Member States by a national from a third country. ${ }^{49}$

At the level of the European Council, with an emphasis on protection of asylum, reference should also be made to the Hague Programme adopted on 4 November 2004 establishing the objectives to be achieved in the area of freedom, security and justice for the period 2005-2010, corresponding to the second phase of the CEAS, as well as the European Pact on Immigration and Asylum, adopted on 15 and 16 October 2008 by the European Council.

In order to strengthen the implementation of the CEAS and at the same time assist and support the Member States directly, the European Refugee Fund ${ }^{50}$ was set up by a Council Decision of 28 September 2000 and the European Asylum Support Office (EASO) was set up by Regulation (EU) No. 439/2010. ${ }^{51}$

\footnotetext{
${ }^{48}$ Cf. Ana Soares Pinto, "Breves Reflexões sobre as implicações do Acórdão do Tribunal Europeu dos Direitos do Homem, M.S.S. no espaço de Liberdade, Segurança e Justiça", in Estudos de Homenagem ao Prof. Doutor Jorge Miranda, Vol. V, FDUL, Coimbra Editora, 2012, p. 74.

${ }^{49}$ With emphasis on the competent administrative and judicial authorities in the Member States, see Annex II, List A, on the evidence and the List B, on the evidence to be considered.

${ }^{50}$ For the period from 1 January 2000 to 31 December 2004. Vide Decision No. 573/2007/EC of the European Parliament and of the Council of 23 May 2007 for the period 2008-2013 and Regulation (EU) No. 516/2014 of the European Parliament and of the Council of 16 April 2014 establishing the Fund for Asylum, Migration and Integration, for the period 1 January 2014 to 31 December 2020. The Fund aims to financially support the efforts of Member States in the development of the common asylum policy, promoting a fair sharing of their responsibilities, in receiving refugees and persons seeking international protection and bearing the consequences of receiving them. In order, to achieve this there is a wide range of legislation, which is European or national, of the various Member States.

${ }^{51}$ In operation since 2011 and with its headquarters in Valletta, Malta. In addition to the EU Member States, it integrates, since 2014, Iceland, Liechtenstein, Norway and Switzerland, as associated countries. It is an EU agency which aims to strengthen cooperation among Member
} 


\subsection{The right to asylum and national law}

Besides the many international and European instruments, of note are the national constitutions ${ }^{52}$ and national asylum laws, which regulate asylum and the protection afforded to refugees, though not in an entirely coincident manner.

With regard to national asylum,,$^{53}$ besides a differentiation in the status between refugees and foreigners, there is no uniformity in Europe. This is because the recent Directives have been fully implemented into the national law of all the Member States, or because of the different nature that is conferred on the right to asylum in some systems. In some, it is a fundamental right that is enshrined by the Constitution and in others, it is viewed as an individual right.

Thus, the uniformisation of refugee status in terms of European law contrasts with the mere harmonization at the level of the different national legal systems.

Despite all efforts to build and develop a Common European Asylum System, in reality, the differences in national legal systems are still being felt, for not all States accept and implement the rules coming from the European institutions.

No regulatory system will be complete, beyond the set of rules and principles that comprise it, unless there is uniform application by national authorities.

Within the Member States, the interpretation and application of European asylum law, which the official authorities (administrative, police and judicial) make, is of particular relevance, since it is through their respective decisions that real European asylum policy is built.

In this context, the role that the courts play in the uniform application EU

States in the field of refugees and asylum by helping them cope with crisis situations and to support those whose asylum and reception systems are subject to particular pressure, as well as, to improve the implementation of the Common European Asylum System (CEAS). It aims at strengthening the cooperation among the Member State and the role of the EASO is to encourage the exchange and sharing of best practices among the Member States; to organize activities related to the collection, analysis and availability of information on countries of origin of people seeking protection international; to design and develop training courses for national administrative and judicial organs of the United competent members on asylum; to collect information useful in identifying the risks of massive influx of asylum seekers and the ability of the States concerned to react in order to enable early warning systems; to prepare emergency measures to deal with these pressures; and where appropriate, to facilitate the relocation of beneficiaries of international protection within the European Union. In implementing the Common European Asylum System (CEAS). The EASO also contributes to the application of this framework inside and outside the Union, to gather information on the processing of applications for international protection in the Member States and national legislation on asylum, to draw up an annual report on asylum in the European Union, and to prepare technical documents on the implementation of European instruments on asylum.

${ }^{52}$ In Portugal Article 33(8) of the Portuguese Constitution, entitled "Deportation, extradition and asylum," expressly provides for the right to asylum to foreigners and stateless persons persecuted or seriously threatened by persecution, resulting in a fundamental right enforceable and invoked before the Portuguese State, with administrative and judicial review, before public authorities and the administrative courts. The regime of asylum and subsidiary protection is implemented in law. Moreover, according to Article 15 of the Constitution, "foreigners and stateless persons or residing in Portugal enjoy the rights and be subject to the duties of Portuguese citizens" regardless of the regular or irregular situation. The expulsion order can only be applied to foreigners, so the right to stay in the national territory differentiates status of Portuguese citizens and foreign nationals, being an exception to the principle of equal rights as set out by Article 15 of the Constitution.

${ }^{53}$ On the right to asylum in the EU Member States, Franck Moderne, "Le droit constitutionnel d'asile dans les États de l'Union européenne”, Paris, 1997; Julia María Díaz Calvarro, "La Ley 12/2009, de 30 de Octubre, de regulación del derecho de asilo y de la protección subsidiaria. Novedades y análisis desde su entrada en vigor", in Anuario de la Facultad de Derecho, Universidad de Extremadura, No. 29, 2011, p. 99-127. 
law is recognized, in all types of matters and, in particular, at the level of European asylum and refugee protection.

Therefore, the EU has highlighted the importance of legal and judicial training ${ }^{54}$ for the construction of a common European system of asylum and refugees, to ensure uniform application, submitted to the same legal framework, within the common area of the EU.

\section{The right to asylum in light of Council Directive 2011/95/EU}

In the context of a Europe suffering from the pressure of migratory flows and the exponential number of incoming refugees and migrants, it is unequivocal that the continent is facing great difficulties and challenges related to the analysis of European asylum. It is important, therefore, to comprehend the normative solutions expressed in Directive No. 2011/95/EU of the European Parliament and of the Council of 13 December 2011, ${ }^{55}$ also called the Qualification Directive which regulates refugee status, the status of asylum seekers and subsidiary protection but also of the exclusion clauses and exclusion of these statutes.

This Directive establishes the rules on the qualification of third country nationals or stateless persons as beneficiaries of international protection as refugees or persons who otherwise are in need of subsidiary protection, as well as the rules for content on the protection granted in order that Member States apply common criteria for the identification of persons genuinely in need of international protection and that the minimum protection is ensured in all Member States.

This establishment aims to assist the competent national bodies of Member States to apply the Geneva Convention, and the criteria and common concepts of asylum policy.

A refugee $e^{56}$ is a person who is a national of a third country, fearing persecution for reasons of race, religion, nationality, political opinion or membership of a social group, is outside the country of his nationality and is unable or, due to fear, is unwilling to avail himself of protection in that country, or a stateless person who being outside the country in which he has his habitual residence for the same reasons, cannot, or due to fear, does not want to return to it, and to whom Article 12, which provides for the grounds of exclusion, does not apply.

Refugee status is reflected by the recognition of a Member State of a national of a third country or a stateless person as a refugee.

A person eligible for subsidiary protection ${ }^{57}$ is a national of a third country or stateless

\footnotetext{
${ }^{54}$ Besides what EASO has made regarding its policy, it also established working groups to prepare studies, bibliographic and jurisprudence collections, including the ECHR, the ECJ and national courts, concerning the interpretation and application of the law European asylum. It is worth mentioning the role of the EJTN - European Judicial Training Network, at the level of training of judges and prosecutors, particularly in terms of European asylum law. The Administrative Law subgroup of the EJTN has understood how important the issue of asylum and refugees is, especially nowadays, for judges who decide such cases, so it has ensured the training of the judiciary on this issue, namely in Portugal, Austria and Finland. In Portugal, the Seminar on European Asylum Law, held at the Centre for Judicial Studies on 5 and 6 November, 2015, was attended by 44 Judges and Prosecutors from 24 Member States. Cf. http://www.ejtn.eu/Templates/Public/Pages/NewsItem. $\underline{\text { aspx?id }=3453}$.

${ }^{55}$ This Directive does not bind the United Kingdom, Ireland and Denmark.

${ }^{56}$ Cf. of Article 2 (d) of Directive Directive No. 2011/95/EU.

${ }^{57}$ Cf. Article 2 (f) idem.
} 
person who does not qualify as a refugee but in respect of which there are substantial grounds for believing that, if returned to his country of origin or, in the case of stateless person to the country in which he is ordinarily a resident, there is a real risk of suffering serious harm within the meaning of Article 15 and which does not apply the exclusion clauses provided for by Article 17 and who is unable or, owing to such risk, unwilling to avail himself of the protection of that country.

On the other hand, the application for international protection is the application for protection from a Member State by a national of a third country or a stateless person who gives the impression that he or she wishes to receive refugee status or subsidiary protection and not expressly to request other types of protection not covered by the Directive, according to Article 2 (h).

The Directive is concerned with approximating the national arrangements on recognition of refugee status and subsidiary protection status as well as the rules regarding their content, to limit or reduce the movements of applicants for international protection between Member States, namely, where such movement is purely caused by differences in legal frameworks. And the reality is that those secondary movements are becoming more frequent. This is because immigrants enter a country, but sometimes do not wish to be registered there because they want to be able to choose the destination country and move to another Member State. This is the asylum-shopping phenomenon. An applicant tries to prevent his or her registration in the country of entry into the EU or submits multiple asylum applications in various countries, so as to be able to choose the host country where he or she will reside.

It is expected that the application of the Directive will be kept under regular review, taking into account the evolution of the international obligations of Member States regarding non-refoulement, the evolution of labor markets and the development of common basic principles of integration. It should be noted that it should not exceed that which is necessary to achieve its objectives, according to the principle of proportionality set out in paragraph 4 of Article 5 of the EU Treaty, which provides that the content and form of Union action should not exceed what is necessary to achieve the objectives of the Treaties.

The Directive is without prejudice to the Protocol on the national asylum law of EU Member States annexed to the TEU and the TFEU, nor does it prevent the Member States from providing for a more favorable regime than regulated by it, according to Article 3.

The third-country nationals or stateless persons authorized to remain in the territory of the Member States for reasons not related to the need for international protection but instead, on a discretionary basis, on compassionate or humanitarian grounds, are not covered by the Directive for it was understood early on, that those who leave their countries for reasons regarding family or personal convenience cannot be considered refugees.

Although the Directive excludes these situations, it highlights the concern over respect for fundamental rights and principles recognized in the CFREU, seeking to ensure full respect for human dignity of asylum seekers and accompanying family members. Hence, one of the principles that is binding on the Member States is the principle of the "best interest of the child", which calls for considerations relating to the protection of the principle of family unity, the well-being of the child, safety issues and the opinions of the child, depending on his or her age and maturity. ${ }^{58}$

${ }^{58}$ Cf. Considering the initial point 16 of Directive. 
To this end, the Directive calls for a broad definition of family member, to take into account different situations involving dependent children, insofar as the family already existed in the country of origin. It includes the following family members: (i) the spouse or unmarried partner in a stable relationship, where that Member State's law treats unmarried couples in the same way as married couples; (ii) the minor children of couples referred to above, provided that they are unmarried (including adopted children) and (iii) the father, mother or adult who, according to Member State, is responsible for the beneficiary of protection, if he or she is a minor (under 18 years of age) or single.

Assuming that the recognition of refugee status is a Sovereign declaratory act of the host State, the queries addressed to the United Nations High Commissioner for Refugees or the European Asylum Support Office (Hereinafter, EASO) can be useful for providing relevant and current information for refugee status determination in accordance with Article 1 of the Geneva Convention. Therefore, considering the role that these organizations play, under international and European law, it encourages the establishment of standards regarding the content of refugee status, in order to help the competent national bodies of the Member States define common recognition criteria of the asylum seeker or need for protection as a result of offences or persecution or even according to the motives for persecution. ${ }^{59}$

Protection against persecution ${ }^{60}$ or serious harm can be provided by organizations, including international organizations, so long as they have the capacity to meet the requirements of the Directive, control a region or a larger area of that territory and as long as that such protection is effective and not of a temporary nature. With regard to internal protection, it shall be provided in a part of the country, allowing the person to travel and remain safe. ${ }^{61}$ But when the actors of persecution or serious harm are the State or its agents, it is assumed that there is no effective protection for the applicant.

This whole system is developed in the Directive with regard to agents of persecution or serious harm and protection agents, which in both cases may be the State itself, parties or organizations controlling the State or a substantial part of the territory or non-State actors, for all of them, as appropriate, can be agents of persecution or harm or actors of protection.

As for the acts of relevant persecution and the reasons for persecution, the Directive further densifies the regime by establishing what they are and on what terms they are covered.

The CJEU ${ }^{62}$ had the opportunity to rule on the concept of "act of persecution" in light of Article 9 (1) (a) of Directive 2004/83/EC, in the sense that not all infringements of the right to freedom of religion, which violates Article 10 (1) of the CFREU, are likely

\footnotetext{
59 Because of its importance, the "Handbook and Guidelines on Procedures and Criteria for Determining Refugee Status", it is worth noting. It has the UN Agency for Refugees, as well as the various studies prepared by working groups made up of judges and academics under the auspices the EASO on its origin and entails elements that administrative and judicial authorities must consider and follow in the interpretation and application of the Geneva Convention (and the European Directives).

${ }^{60}$ Analysing the concept of "persecution", Andreia Sofia Oliveira Pinto, "Algumas questões sobre os pressupostos do reconhecimento de protecção internacional a estrangeiros em Portugal", in Estudos de Homenagem ao Prof. Doutor Jorge Miranda, Vol. I, FDUL, Coimbra Editora, 2012.

${ }^{61}$ In this case there is a situation of displaced persons, who are forced to leave their homes and place of residence, due to violations of their human rights to settle in different locations in their own country.

${ }^{62}$ Cf. Joined Cases C-71/11 and C-99/11 of 05/09/2012 (Grand Chamber).
} 
to constitute an act of persecution within the meaning of that provision of the Directive.

One of the conditions for qualification for refugee status under the Geneva Convention is the existence of a causal link between the reasons for persecution, such as race, religion, nationality, political opinion or membership in a particular social group, and the acts of persecution or the lack of protection against such acts.

In order to densify the common concept of the ground of persecution associated with membership in a particular social group, the issues that are considered relevant are those related to the applicant's gender and gender identity and sexual orientation, related to certain legal traditions or customs, resulting in genital mutilation, forced sterilization and forced abortion for example, to the extent that they relate to the applicant's well-founded fear of persecution.

Important clarification is that which tells us that while an entire population or a group of people of a country is generally exposed to risks, such does not constitute in itself an individual threat, which, in the light of the Directive, can be regarded as justifying refugee status.

In addition to the conditions on which refugee status depends, the conditions for granting subsidiary protection are also established, complementing the refugee protection provided for by the Geneva Convention. The Directive defines the common criteria to be met by applicants to qualify for subsidiary protection, according to the bindings undertaken by States in the instruments concerning human rights.

The Directive aims to establish a uniform status for refugees and persons eligible for subsidiary protection, so that the beneficiaries of subsidiary protection status have the same rights and benefits as refugees under the Directive.

In terms of social welfare, international protection system is assured, providing for social assistance and means of subsistence, under the Member State's social security system. It should cover at least minimum income support and assistance in case of illness and covering physical and mental health care, pregnancy and parental assistance, as is granted to nationals under national law.

Moreover, although it is expected that Member States make efforts to solve problems of access of beneficiaries to training opportunities related to employment and vocational training, the Directive does not apply to benefits for promoting education, although it addresses the protection regarding obtaining recognition of diplomas, certificates or other evidence of formal qualifications, particularly when documentary evidence is lacking.

Also included in the scope of Directive are integration programs, including language training, as well as the provision of information on individual rights and obligations relating to their protection status in the Member State.

In relation to the granting of benefits with regard to access to employment, social security, health care and access to integration facilities, Member States may require the prior issue of a residence permit.

As a result of large-scale migratory movements in the EU space today, it is a major challenge for Member States to comply with the Convention of Geneva and EU law concerning the protection of refugees and asylum seekers. 